\title{
Geleceği Geçmişte Aramak: 20. Yüzyıl Mısır Tarih Yazıcılığında Kadim Köken Teması
}

\author{
Hilal Livaoğlu Mengüç*
}

"Yeni Misır, bir buluş ya da bir keşif değildir. Yeni Mısır, kadim Mısır (mirası) üzerine inşa edilecektir.**"

$\ddot{O} \mathbf{z}$

20. yüzyılın ilk çeyreğinde, Mısır'ın mutlak bağımsızlığına gittiği düşünülen bir yolda, geleceğe yönelik umutları pekiş̧irmek amacıyla eski Mısır'ın parlak tarihinin idealize edilmesiyle sonuçlanan bazı fikir akımları ortaya çıkmışır. 19. yüzyılın sonlarına doğru ortaya çıkan ve Mısır Milliyetçiliği ya da Mısırcılık düşüncesinin ilkelerini esas alan fakat bu anti-sömürgeci söyleme bir miktar hümanizm de ekleyen antik mirasçılardan bazıları, çeşitli gazetelerde kaleme aldıkları makalelerde kendilerini "Firavuncu" olarak nitelendirecek kadar ileri gitmiş̧lerdir. Firavuncular, Kadim Mısır medeniyetini dünya medeniyetlerinin kaynağı olarak görmüş ve Mısır halkına görkemli geçmişiyle gurur duymasını salık vermişlerdir. Antik dönem Mısır'ın Mısırlılar tarafından yönetildiği yegane dönem olarak idealize edilmiş ve modern Mısırlılar yüksek bir medeniyetin mirasını devralmış bir halk olarak nitelendirilmişlerdir. Ülkenin Firavunlar döneminde bilim ve sanat alanlarında kat ettiği mesafe, Ortaçağ Mısır'ının "sin(diril)mişliği" ile karşılaştırılmış ve yeniden "önce Misırlı" olmak, Misırlılara yegane çıkar yol olarak sunulmuştur. Mısır tarih yazıcılığındaki kadim köken vurgusu, 1930'ların ikinci yarısından itibaren popülerliğini yitirmiş ancak 1960'larda ve 1990'larda antik Mısır'a yönelik ilgilinin artmasıyla 1920'lerdeki kadar yoğun olmasa da yeniden popülerlik kazanmıştır. $\mathrm{Bu}$ çalışmada, 20. yüzyılda Mısır'ın seküler eğilimli entelektüelleri arasında geniş biçimde işlenen kadim köken temasının nasıl geliştiği, hangi tarihî-kültürel dayanaklardan hareketle oluştuğu, Mısır'ın önde gelen aydınları tarafindan gerek dönemin önemli basın organları gerekse telif eserlerde serdedilen görüşleri, kadim köken temasının Mısır tarih, kültür ve edebiyatına yönelik ne tür okumalara temel teşkil ettiği gibi hususlar irdelenmeye çalışılmıştır.

Anahtar Kelimeler: Tarih, Misırcılık, Antik Mısır, Mısır Kimliği, Bölgesel Milliyetçilik

\footnotetext{
* Dr., İstanbul Üniversitesi, TR, İlahiyat Fakültesi, orcid.org/0000-0002-0473-0815, hilal.menkuc@istanbul.edu.tr

** Taha Hüseyin, Müstakbelü’s-sekâfe fî̀ Mısr (Kahire: Dârü’l-meârif, t.y.), 18.
} 


\title{
The Theme of Ancient Roots in the 20th Century Egyptian Historiography
}

\author{
Hilal Livaoğlu Mengüç*
}

\begin{abstract}
In the first decades of the 20th century, on a path which was thought to lead to Egypt's absolute independence, some currents of thought emerged resulting in the idealization of the brilliant history of ancient Egypt in order to consolidate hopes for the future. The idea of advocating the ancient heritage as a dominant part of modern Egyptian identity was actually connected to the idea of Egyptian nationalism or of Egyptianism which emerged towards the end of the 19th century, but also added some humanism to this anti-colonial discourse. The advocators of the ancient heritage went so far as to describe themselves as "fir"awniyya" (i.e. Pharaonicist) in the articles they wrote in various newspapers. They saw the ancient Egyptian civilization as the source of world civilizations and advised the Egyptian people to be proud of their glorious past. The ancient period was idealized as the only period when Egypt was ruled by the Egyptians, and the modern Egyptians were described as a people who inherited the heritage of a high civilization. The emphasis on ancient origins in Egyptian historiography has lost its popularity since the second half of the 1930s, but has regained it, although not as intense as in the 1920s, with increasing interest in ancient Egypt in the 1960s and 1990s. In this study I try to examine how the theme of ancient origins developed in the 20th century among the secular-oriented or non-conservative intellectuals of Egypt and how it developed from historical-cultural bases, the views of the important press organs and the intellectuals of the ancient origins in ancient books and copyright works, Egyptian history, culture and literature, such as what constitutes the basis for reading.
\end{abstract}

Keywords: History, Egypt, Egyptianism, Egyptian Identity, Regional Nationalism

* Dr., Istanbul University, TR, Faculty of Theology, orcid.org/0000-0002-0473-0815, hilal.menkuc@istanbul.edu.tr 


\section{Giriş}

Mısır'ın antik dönemden İngiliz işgali sonrasına uzanan hikayesi, 1919 sonrası seküler-milliyetçi tarih yazımında sıklıkla, yabancılar tarafindan yönetilen ve Misırlılar tarafından yönetilen Misır olmak üzere kabaca ikiye ayrılır. Büyük ölçüde ideolojik temelli olan bu ayrım ve onun temellendirdiği tarih okuması, 1952 Hür Subaylar Devrimi ve Cemal Abdunnasır iktidarı ile pekişmiş ve eğitim müfredatına girerek yaygınlık kazanmaya başlamıştır. ${ }^{1} \mathrm{Bu}$ bağlamda bilhassa 20. yüzyıl başlarından itibaren sekülermilliyetçi aydınların, Mısır kimliğinin tarihsel uzantılarını bulma noktasında referans aldığı dönemlerden biri de Firavunlar dönemi olmuştur. Bu durumda, halkın İngiliz idaresine duyduğu öfkenin yanı sıra, Hilafetin ilgası ile birlikte İslam ortak kimliğinde birleşmeye yönelik talep ve duyarlılığın nispeten azalması da etkili olmuş görünmektedir. ${ }^{2}$

Mısır'da 1922 yılında gerçekleştirilen bir keşif ve bu keşfe gösterilen ilgi, Napolyon'un Misır Seferi ile başlayan fakat tam anlamıla yeşermesi 19. yüzyıl sonlarını bulan Antik Mısır merakının popülerleşmeye başladığını göstermektedir. Milattan önce XIV. yüzyılda hüküm sürmüş olan Kral Tutank-Amon'un mezarının Misır-bilimci Howard Carter tarafindan keşfedilmesi, ${ }^{3} 1919$ sonrasında yeni Mısır'ın inşası sürecinde o kadar iyi konumlanmıştır ki, kadim Mısır'ın önemli krallarından biri, ulus olarak yeniden doğuşun sembollerinden biri olarak yansitılmıştır. ${ }^{4}$ İngiltere'nin

Bu düşüncenin mükemmel bir temsili, Ahmed Lütfi es-Seyyid'in oğlu Afaf Lütfi esSeyyid Marsot'tur. Marsot, Türkçe'ye de çevrilen Mısır tarihine dair bir eserinde, eserin ana temasının "Mısır halkının idarecilerine yabancılaşması" olduğunu, bu yabancılaşmanın Arap fetihleriyle başlayarak 1952'ye kadar sürdüğünü yazmaktadır. Bkz. Afaf Lütfi es-Seyyid Marsot, Mısır Tarihi: Arapların Fethinden Bugüne, çev. Gül Çağalı Güven (Tarih Vakfı Yurt Yayınları, 2010), ix.

2 Bu konudaki tartışmalar için bkz. Hilal Livaoğlu Mengüç, Mısır Basınında Hilafet Tartışmaları 1922-1926 (İstanbul: Libra, 2018).

3 Shaw-Nicholson, British Musem Dictionary of Ancient Egypt (Cairo: American University in Cairo, 1996), 297.

$4 \quad$ Israel Gershoni ve James Jankowski, Egypt, Islam and the Arabs: The Search for Egyptian Nationhood, 1900-1930 (New York: Oxford University Press, 1987), 168. Dönemin önemli şairlerinden Ahmed Şevkî, duyduğu coşkuyu Tutank-Amon'a yazdığı dizelerinde dile getirmiştir. Muhammed Hüseyin Heykel'in şu satırlarında aynı hissiyatı dillendirmektedir: "Konuş! Belki sözlerin bize rehber olur ve belki söyleyeceklerin bizi teselli eder. Sen güneş ve aydan geldiğini iddia eden, gölgesi atalarımızın uygarlığına, yüce yapılara ve büyük emanetlere vuran, kudretli Firavun'u görmedin mi?... Bize tiranlık eden, bizi köleleştiren, adamları bizi eşek sürer gibi önüne katıp ve sonra soylu fatihlerden oluşan küçük bir birlik tarafindan yenilgiye 
kısmi olarak Mısır'dan çekilmesi ve mezarın keşfinin aynı yıl gerçekleşmesi, arkeoloji ve politikayı belki de dünya tarihinde çok az görünür şekilde birbirine yaklaştırmıştır. Tarih dışındaki alanlarda bağımsızlığın ne ölçüde gerçekleştirilebildiği tartış1lsa da, Mısırlı bazı entellektüeller 1922'den sonra ilk kez, hiç olmazsa kazılarla toprağın üstüne çıkarılan tarihi miraslarına tek başlarına sahip olma hakkını elde ettiklerini düşünmüşlerdi. ${ }^{5}$

\section{Antik Mısır Keşifleri ve "Kültürel Uyanış"}

Misır'da modern arkeolojik kazıların tarihi Fransa Kralı Napoleon Bonaparte'ın Mısır seferini gerçekleştiği yıllara dayanır. ${ }^{6} 1789$ yılında Fransız ordusu ile birlikte Mısır'a gelen uzman heyetinin başlattığı sistematik kazı çalışmaları, Jean Champollion'un (1790-1832) hiyeroglif yazısını deşifre etmesi ile modern Mısır-bilimi ortaya çıkarmış, 1828'de İskenderiye'de, 1836'da ise Kahire'de modern Misır-bilim uzman ve meraklıları -ve hatta turistler- için lokaller oluşturulmasıyla Mısır'ın kadim tarihine duyulan merak en üst seviyeye çıkmıştı. Başladığı dönemlerde kazı çalışmalarının neredeyse tamamen Avrupalı kişi ya da kurumlar tarafından gerçekleştirilmesi; sayısız tarihi eserin Avrupa'ya götürülerek Berlin, Londra, Roma, Paris gibi Avrupa başkentlerindeki müzelerde sergilenmesi ya da -kazının yapılması kişisel bir inisiyatifle gerçekleştirildiyse- ulaşılan tarihi eserin özel mülkiyet kapsamına girmesi sonucunu doğurmuştur. Mehmet Ali Paşa duruma el koyarak 1835 tarihli bir fermanla Misır-bilime ve antik mirasa sahip çıkana dek durum böyle sürmüş, ${ }^{7}$ Mehmet Ali

uğratılan Sezar'ı görmüşsündür... (Sfenks dile gelir:) Sizi güçlendirecek bir şeyi sizin için muhafaza ettim, güzelliği taşstan iyi muhafaza eden bir şey yoktur... Umudun sabahı umutsuzluğun karanlığını silip süpürür, uzun zamandır beklenen şafak vaktidir şimdi." Alıntılayan ve tercüme eden Mustafa Köse, "Heykel ve Milli Edebiyat Hakkındaki Görüşleri," Şarkiyat Araştırmaları Dergisi, vol. 9. (Bahar 2003), 4.

5 Donald Malcolm Reid, Whose Pharaohs: Archeology, Museums and Egyptian National Identity from Napoleon to World War I (Cambridge: Cambridge University Press, 1990), 293.

6 Avrupalıların Mısır'a ilgisi daha evvelki yüzyıllara dayanmaktadır. Fakat Napolyon döneminden önceki kazılar daha çok kişisel inisiyatiflerle dağınık şekilde gerçekleştirilmekte olup hiyeroglif yazısı okunamadığı için henüz Mısır-bilim doğmamıştı.

7 Donald Malcolm Reid, Whose Pharaohs, 39. Mehmet Ali Paşa'y1 -geç de olsa- böyle bir tavır almaya iten nedenler spekülasyona açıktır. Uzak tarihe duyulan yürekten bir ilgi ve merak, antik eşyaların daha sonra Avrupa devletleriyle yapılacak anlaşmalarda 
Paşa'nın kazılarla ulaşılan eserlerin Avrupa kentleri yerine Mısır'da korunmasını emreden bu fermanı aynı zamanda Misırlı ulemanın dikkatini kadim Mısır mirasına çeken bir uyarıcı olmuştur. ${ }^{8}$

Rifâ'a et-Tahtâvî, modern dönemde Misır-bilimin öneminden bahseden ilk aydınlardan biridir. Fransa'da geçirdiği yıllar Tahtâvî’nin gözlerini antik Mısır'a çevirmiş, Ezher'li genç imam, Paris müzelerinde sergilenen antik Mısır koleksiyonlarına büyük ilgi göstermişti. Bu yıllardan çok sonra Mısır'da kaleme aldığı Menâhicü'l-Elbâb'ta kadim Mısır'ın özgün bir medeniyet olarak ulaştığı seviyeyi detaylı biçimde anlatmış, hayranlık duyduğu bu medeniyeti sahiplenmiş ve Mısırlı Müslümanların Kıptîlerle birlikte bu büyük ve değerli mirasın varisi olduğunu dile getirmişti. ${ }^{9}$ Rifâ'a bu mirasa sahip çıkma gayesiyle ülkesinin tarihini konu alan bir eser telif etmeye başladı fakat yalnızca birkaç bölüm yazabildi. Yazabildiği ilk bölüm ise Mısır'ın İslam öncesi tarihiyle ilgili bölümdü. ${ }^{10}$

Heyecanla bu yeni alana giren yalnızca Tahtâvî değildi. Tıpkı onun gibi Avrupa'da eğitim görmüş Ermeni asıllı Yusuf Hekekyan (1807-1875) ile Ahmet Kemal (1851-1923) gibi Misırlı entelektüellerin Misır-bilimi sahasında varlıklarını hissettirmeleri ile birlikte bu alandaki Avrupa nüfuzu bir nebze de olsa kırılabildi. Kodları hızla çözülen antik mirasa dair ve ona özgü pek çok detay, Mısırlı elitler arasında ilgi konusu haline geldi. Mehmet Ali Paşa'nın yaptırdığg lotus çiçekleriyle bezeli cami ya da 1829 tarihli bir Vekayi-i Mısriyye sayısının logosunda Mısır'ı sembolize etmek için kullanılmış bir piramit çizimi, Mısır yönetimi ve Mısırlı aydınlar arasında

bir çeşit pazarlık objesi olarak tasavvur edilmesi ya da -Mehmet Ali Paşa dönemi için belki düşük bir ihtimal olarak- antik kazılarla geçmişine 1şık tutulan Mısır'ın geleceğine yönelik umutlar söz konusu ilginin nedenleri arasında sayılabilir. Fakat Paşa tarafından gönderildikleri Avrupa'da ilim tahsil eden Mısır'ın parlak beyinlerinin Çerkez yönetime tarihi eserler konusunda takınılan duyarsız tavır konusunda yaptıkları uyarılar Mehmet Ali'nin tarihi eser politikasını ciddi şekilde etkilemiş görünmektedir. Hekekyan'ın konu hakkındaki beyanı için bkz. Donald Malcolm Reid, 61.

8 Hilal Livaoğlu Mengüç, Misır'da Antik Mirasa Dönüş: Firavunculuk Tezi (İstanbul: Libra Yayınları, 2018), 46-47. Müslüman Mısır'ın tarihinde kadim Mısır üzerine yazan tarihçiler de vardır. Bu tarihçilerin ayrıntılı bir dökümü için bkz. Okasha elDaly, Egyptology: The Missing Millenium Ancient Egypt in Medieval Arabic Writings (Australia: Cavendish Publishing 2005), 161-183.

9 Rifâ'a et-Tahtâvî, Menâhicü'l-elbâb ([y.y]. 2002), 178-181.

10 Tahtâvî'nin Envâru't-tevfiki'l-cedîd adlı eserinden naklen, Ahmed Ahmed Bedevî, Rifâ'a Râfî et-Tahtâvî (Lecnetu'l-Beyâni'l-Arabî, 1959), 109. 
antik mirasa karşı gelişen bu ilginin ilk habercileriydi. ${ }^{11} 1886-87$ yıllarında yayınlanan, 20 ciltten müteşekkil ve Misır'ın ilk topografik ansiklopedisi olan, yazarı Ali Mübarek'in Fransız Description de l'Egypte'e karş1lık olarak kaleme alındığı düşünülen (kendisi de Fransızca eseri "Fransız el-Hitat" diye adlandırmaktayd1) "el-Hitatu't-Tevfikiyye el-Cedîde"sinde de Firavunlar dönemine ait bilgilere geniş yer ayrılmışt1. ${ }^{12} \mathrm{Bu}$ dönemden itibaren Mısır-bilim, ağırlıklı olarak Kıptî tarihçi ve arkeologların Kıptî tarihine yönelik araştırmalarıyla paralel olarak ilerlese de, Mısır'ın Müslüman entelektüelleri de Misır-bilim sahasına giderek artan bir alaka gösterdi. Bu kişiler arasında, Türk milletine sevgisi ve Mısır'daki muhafazakar milliyetçi çevrelere yakınlığı ile meşhur Ahmed Şevki de vardı. Şevki, 1890'lardan itibaren Firavunlar dönemi kahramanlık hikayelerini konu alan şiirler kaleme almıştı.

Kadim mirasa ilgi 1920'li yıllar boyunca hem tarihçiler hem de edebiyatçılar arasında yoğun olarak mevcuttu. Bunlardan biri de, hayatının son demlerinde sahabe biyografileri kaleme alacak olan Muhammed Hüseyin Heykel'di. Heykel, bahsedilen arkeolojik keşiflerin oluşturduğu coşkulu atmosferi satırlarına şöyle aktarmıştı:

“Bugün hepimiz Tutank-Amon'un mezarının keşfini coşkuyla alkışlyoruz. Firavunların on sekizinci hanedaninın tesis ettiği medeniyet bizlere büyük onur veriyor ve kendimize soruyoruz: Atalarımız medeniyette böyle bir zirveye çıktılarsa, biz neden çıkamayalım?"'13

Mısır'ın yeniden doğuşuna tanıklı̆̆ın heyecanını yaşayan bir başka entelektüel de Ahmed Hüseyin idi. Hüseyin, 1928 yılında mezarın bulunduğu Luksor kentine yaptığı ziyarete ilişkin notlarında, ${ }^{14}$ "ruhunda ve aklında giderek artan bir yeniden doğmuşluk hissi yaşadiğını” yazdı. Luksor' da geçirdiği o gün, yepyeni bir dünyanın kapılarını kendisine aralamışt. ${ }^{15} \mathrm{Ah}$ med Hüseyin, bin yıllar sonra canlılıklarını hala muhafaza etmekte olan freskler karşısında hissettiklerini okuyucuya şöyle aktarıyordu:

\footnotetext{
11 Reid, Whose Pharaohs, 54-59.

12 Ali Mübarek Paşa, el-Hitatu 't-tevfikiyye (Kahire 1990), II, 146-158.

13 Heykel, "Misr el-hadîse ve Misr el-kadîme," es-Siyasetü'l-Usbûiyye, 27 Kasım 1926, 10.

14 Ahmed Hüseyin, Îmânî (Kahire, 1936), 20-33.

15 Hüseyin, "Îmânî" 20-21.
} 
"Zamana, güneşe, yağmura, dayanılmaz sıcăga, soğuğa ve her tür hava şartına meydan okuyan bu büyülü freskler tüm dünyayı şaşkına çevirmiş durumdadır. Bu freskler her türlü yok edici güce adeta gülerek karşılık vermektedir. Bugüne dek o kadar parlak ve canl gelmişlerdir ki, onlara baktığınızda daha dün yapıldıklarını düşünebilirsiniz. Ne kadar da muhteşem!'”6

Günümüze neredeyse hiç bozulmadan orijinal biçimleriyle ulaşan bu freskler yazara göre, Mısır'ın ihtişamlı günleriyle bağlantının kopmadığını gösteriyordu. Araya giren onlarca asır ve istilalar Mısır'1n kadim kökleriyle olan bağını koparamamışt1. ${ }^{17}$ Zeki Salih'in Ocak 1927'de kaleme aldı̆̆1 makalesinde de belirttiği üzere; "Misır'ın kalbi asırlarca süren sakinliğin ardından yeniden hareket etmeye başlamıştı." Bir zamanlar Misır'1 içinde bulunduğu karanlıktan çıkaran Tutank-Amon, bu kez na'şıyla bu vazifeyi ifa edecekti. ${ }^{18} 1919$ yılından itibaren tasarlanmaya başlanan ve 10 Mayıs 1928 tarihinde Kral Fuâd, yüksek yargı üyeleri, İngiliz yüksek komiseri, dönemin başbakanı Mustafa en-Nahhâs, bakanların tümü, milletvekilleri ve nihayet Ezher şeyhlerinden oluşan bir kalabalığın önünde örtüsü kaldırılarak alkışlanan anıta Nahdatu Misr [Tr. Misır'ın silkinişi] isminin verilmesi bu atmosfere son derece uygun düştü. Anıtın yapımında antik dönem mimarisini çağrıştıran Mısır granitleri seçilmiş ve bu taşlar tıpkı o zamanlarda olduğu gibi ham halde Nil boyunca taşınarak kuzeye getirilmişti. ${ }^{19}$

Dönemin önde gelen gazetelerinden el-Mukattam'da yazan Naşid Seyfîn, Misır'ın bilinen büyük medeniyetlerin tümünü kronolojik olarak öncelediğini savunurken ${ }^{20}$, Ahmed Hüseyin de Misır'1 medeniyetlerin beşiği olarak nitelemiş, insanların yaban hayatı yaşadığ 1 bir dönemde ortaya çıkan bu büyük medeniyetin geçmiş ve gelecek bütün medeniyetleri utandırdığını

16 Ahmed Hüseyin, Îmânî, 18-39. Benzer bir coşku "Firavuncu bir edebiyat" arayış1 içinde olan Mahmud İzzet Musa'da da görülür. Musa, Luksor sakinlerinin bu muhteşem eserlerle iç içe yaşadıkları için ne kadar şanslı olduklarını anlatmaktadır. Bkz. M. İzzet Mûsâ, “el-Edebü'l-Fir'avnî," es-Siyâsetü'l-usbûiyye, 3 Ağustos 1929, 20.

17 Bugünkü Mısırlıların hem genetik hem de kültürel bakımdan mirasçısı konumunda olduklarını yineleyen mühim bir anlatı olarak 1957'da Ahmed Fahri tarafindan kaleme alınan Misr el-Firavniyye adlı eserde "... (Mısırlılar) ataları nasıl yaşıyor idiyse hala öyle yaşıyorlar ve damarlarında hala atalarının kanı akıyor.” Bkz. Ahmed Fahrî, Mısr el-Fir'avniyye (Kahire: el-Hey'eti'l-mısriyyeti'l-âmme li'l-kütüb, 2012), 8.

18 M. Zeki Sâlih, “İhyâu hulûki'l-kavmî,” es-Siyâsetü'l-Usbûiyye, 15 Ocak 1927, 31.

19 Israel Gershoni ve James Jankowski, Egypt, 186.

20 Nâşid Seyfîn, “Mısr fir'avniyye lahmen ve demmen," el-Mukattam, 10 Eylül 1930, 7. 
söylemiş ve Mısır'a insanlığı barbarlıktan medeniyete yükseltme payesi biçmişti. ${ }^{21}$ Firavuncu olduğunu kuşkuya yer bırakmaksızın ilan eden az sayıda yazardan biri olarak Ahmed Hüseyin ${ }^{22}$ yurttaşlarına bu mirasa sahip çıkmalarını ve kadim tarihleriyle övünmelerini salık veriyordu. ${ }^{23}$ el-Belağ editörü Abdulkadir Hamza tarafından da paylaşılan bu diskur aynı zamanda Firavuncu düşüncenin pragmatik alt metnini de açığa vurmakta idi. Firavunculuk, idealize edilen geçmişe dayanırken, yüzünü -romantik biçimde- o geçmişe değil, yeniden tasarlanacak bir geleceğe dönüyordu. Antik döneme dönüş yalnızca Mısır'ın yabancı yönetimler tarafından örselenmiş özgüveninin yerine gelmesi için değil, bu özgüvenin Mısır'ın tamamen bağımsızlaştırılarak yeni dünya düzeni içerisinde hak ettiği yeri alması için de önemli idi:

"Atalarımızın kalıntılarına onlardan manevi anlamda güç almak için değil, yüzylllar süren aşağılanma ve köleliğin bünyemizde yarattı̆̆ aşağıllı kompleksinden kurtulmak için bakmallyız. Atalarımızı ziyaret etmeliyiz. Dünyanin her yerinden buraya bir ibadet vecdi içerisinde gelenlere, bizlere atalarımızla aramızdaki o sarsılmaz bağı hatırlatanlara kulak vermeliyiz. ${ }^{24}$

Abdulkadir Hamza burada bir yandan geçmişi geleceğin inşasında kullanmayı amaç edinmek gerektiğinden bahsederken bir yandan da kadim köken temasını işleyen entelektüeller için oldukça önemli bir meseleye, yabancı yönetimlerin Mısır halkı üzerindeki olumsuz etkisine değindi. Hamza'nın, Mısır halkını millî mirasına sahip çıkmaya davet ederken geldiği bu nokta, yani Mısır'ın yabancılar tarafindan yönetilmeye mahkum olduğu teması, milli bir tarih yazımına çağrıda bulunan aydınların hedef tahtasına koydukları ve kesin olarak savaşılmasını salık verdikleri temel telakkilerden biri olmuştur. ${ }^{25}$

${ }^{21}$ Ahmed Hüseyin, “Misr fir'avniyye (3),” el-Mukattam, 26 Eylül 1930, 11.

22 Kendi ifadeleriyle: "Firavunculuk konusunda takıntılı hale geldim. Firavunculuğumun delilik boyutuna gelmesiyle anılır oldum. " Hüseyin, Nisfu karnin maa'l-Urûba ve kadiyyâti Filistin (Sidon 1971), 29.

23 "Sizlere Firavunî bir Misırlılıktan, sizin Firavunî Mısırlılı̆̆ınızdan bahsediyoruz. Zira büyüklügüüüz ve ihtişamınız bu kimlikte yatmaktadır. Sizlere, atalarınız gibi olduğunuza ve onların izzetini yeniden kazanmanı gerektiğine inanmanızı söylüyoruz. Ey Misırlı, büyüklüğüne inan!” Ahmed Hüseyin, "Misr fir'avniyye (3)," 11.

25 Hilal Livaoğlu Mengüç, Mısır'da Antik Mirasa Dönüş, 51. 
Mısır tarih yazıcılığında kadim köken teması çerçevesinde adından bahsedilmesi gereken bir diğer entelektüel de Ahmed Lütfi es-Seyyid (18721963)'dir. Seyyid, Muhafazakar milliyetçi çizgideki Hizbu'l-Vatanî hareketi içerisinde başladığı siyasi yaşamına Cenevre'deki siyasi temaslarının da etkisiyle seküler milliyetçi çizgideki Hizbu'l-Ümme partisini kurarak devam etti. Partinin ilk yayın organı olan el-Cerîde'nin 1907'de neşredilmeye başlanmasıyla, Ahmed Lütfi es-Seyyid'in savunduğu ve Misır'ın kendi kurtuluşunu başka millet ve devletlerin kudretinde değil kendi kuvvetinde araması gerektiği kanaati de Mısırlı aydınlar arasında yaygınlaşmaya başladı. el-Cerîde'nin devamı niteliğinde olan es-Siyâse gazetesinde de benzer düşünceler, Muhammed Hüseyin Heykel (1888-1956), Selâme Mûsa (1887-1958), Abdülkadir Hamza (1880-1941), Taha Hüseyin (18891973) ve Tevfik el-Hakim 1898-1987) gibi dönemlerinin önde gelen entelektüelleri tarafından savunuldu.

1920'li yılların Firavuncu atmosferinde değer atfedilen unsurlardan biri de antik dönemden bugüne Mısır mirasının taşıyıcısı olarak görülen kırsal kesimdeki yaşam ve bu yaşamın en önemli figürleri olan fellahlar idi. Mısırlı çiftçilere verilen bir isim olmanın ötesinde fellah, bu dönemde öz Mısırlı11ğın simgesi haline gelmişti. Muhammed Hüseyin Heykel daha 1910'lu yıllarda, daha sonra Zeyneb adıyla yayımlayacağ 1 ve kırsal hayata ilişkin bir romantizm içeren romanını el-Cerîde'de dizi halinde yayımlarken "Mısrî fellah" rumuzunu kullandi. ${ }^{26}$

$\mathrm{Bu}$ dönemde Mısır siyasetinin en önemli figürü olan Mısır eski başbakanlarından Sa'd Zaglûl'un liderliğiyle Mısır'ın bağımsızlığını kazanma yolunda önemli adımlar atması ve Zağlûl'ün halkı nezdinde ulusal kahraman haline gelmesi de kırsal kesimden gerçek bir Misırlı prototipi olarak onun biyografisine dikkatleri çekmiş, Zağlûl'ün bu özelliği bilhassa kadim köken temasını işleyen aydınlar tarafından gururla ifade edilmişti. Dönemin seküler milliyetçi çizgideki aydınlarından Abbas Mahmûd el-Akkâd, Zaglûl'ün fellah kökenlerine vurgu yapmış, onun tam da bu sebeple Misırl1lar için ideal lider olduğunu ifade etmişti. ${ }^{27}$

26 Muhammed Hüseyin Heykel, Zeyneb (Beyrut, 2006), 19. Heykel'in biyografisini kaleme alan Muhammed Seyyid Muhammed de Heykel'in varlıklı bir aileden gelmesine rağmen fellah rumuzunu kullanmasını onun bu figüre yüklediği anlam ve Misırcılık düşüncesine matuf olduğunu yazmıştır. Bkz. Muhammed Seyyid Muhammed, Heykel ve's-siyâseti'l-usbû 'iyye (Kahire, 1996), 90.

27 Abbas Mahmud el-Akkâd, Sa'd Zaglûl Zaîmu's-sevra (Kahire: Hindâvî, 2013), 157. Sa'd Zaglûl de bazı siyasi söylevlerinde Mısırlıların, yeryüzündeki en eski medeniyetin varisleri olduğunu vurgulamıştı. 
1908 y1lında kurulan ve 1952 'de Kahire Üniversitesi'ne dönüşecek olan Mısır Üniversitesi'nin de Mısırcılığın kültürel alanda hakimiyet sağlamasında büyük rolü oldu. Misır'ın modern anlamdaki ilk üniversitesi olan bu kurumun faaliyet göstermeye başlaması, geleneksel metotlarla İslami İlimler eğitimi veren Ezher'in o zamana kadarki tartışılmaz hakimiyetini de sarstı. Üniversitenin kurucuları arasında yer alan, devrim sonras1 M1sır'ının kültür politikalarında son derece etkili bir aydın olan Ahmed Lütfi es-Seyyid'in ${ }^{28}$ düşünceleri burada yürütülen eğitim ve araştırma faaliyetlerini de büyük ölçüde yönlendirdi. ${ }^{29}$ Özellikle 1919 Devriminden sonra devlet üniversitesine dönüştürülen ve dinler üstü kimliği vurgulanan kurum, programında antik Mısır çalışmalarına yoğun biçimde yer verdi. ${ }^{30}$ Taha Hüseyin, Muhammed Hüseyin Heykel, Abdülkadir Hamza gibi Mısırcılığa ve Firavuncu düşünceye popülerlik kazandıran isimlerin hepsinin yolu bir şekilde Misır Üniversitesi'nden geçmişti.

1920’lerde Antik Mısır üzerine yazan bir başka Mısırlı tarihçi olan Muhammed Şefik Gurbâl de Misır Üniversitesi’nin yetiştirdiği önemli tarihçiler arasında idi ve Mısır Müzesi'nin açılmasına öncülük etti. Yüksek öğrenimini İngiltere'de tamamlayan ve ünlü İngiliz tarihçi Arnold Toynbee'nin de öğrencisi olan Gurbâl'in ${ }^{31}$ 1927'de basılan Kitâbu't-târîhu'l-kadîm ${ }^{32}$ adlı eseri, kendisinden sonra eski Mısır'a dair yazan tarihçiler için de önemli bir müracaat eseri oldu. ${ }^{33}$

\section{Kadim Köken Temasında Kıpti Kimliği ve Selâme Mûsa}

Mısır Üniversitesi'nin 1919 Devrimi sonrasında kaydığı seküler zemin şüphesiz, eğitim müfredatının düzenlenmesini olduğu kadar hoca profili-

Muhammed Abduh'un öğrencisi olan ve siyasi kariyerine Mustafa Kâmil'in Hizbu'lvatanî çizgisinde başlayan Ahmed Lütfi, 1897'de Cenevre'deki siyasi temaslarından sonra Mısır'ın kaderini kendi başına belirlemesi gerektiğine kanaat getirerek muhafazakar kanattan ayrılarak seküler-liberal çizgideki Hizbu'l-ümme'yi kurdu. Ahmed Lütfi es-Seyyid, Kıssatu Hayâtî (Kahire: Dâru'l-hilâl, 1982), 35.

29 Ahmed Lütfi es-Seyyid'in politik görüşleri hakkında ayrıntılı bir analiz için bkz. Charles Wendell, The Evolution of Egyptian National Image:From its Origins to Ahmad Lütfi al-Sayyid (Los Angeles: University of California Press, 1972), 201-294.

30 Reid, Cairo University and the Making of Modern Egypt (Cambridge University Press, 1990), 31 .

31 Hilal Görgün, "Muhammed Şefik Gurbâl,” DİA, XIV, 199.

32 Muhammed Şefik Gurbâl, Kitâbu 't-târîhi'l-kadîm (Matbaatu'l-hadîse: Kahire, 1927).

33 İbrahim Nemîr Seyfüddîn ve diğ., Mısr fi usûri-l-kadîme (Kahire: Mektebetu Medbûlî, 1991). 
ni de etkiledi. 19. yüzyılın başlarından itibaren Kıptilerin Mısır bürokrasisinde neredeyse Müslümanlar kadar etkili oldukları, hatta İngiliz işgali döneminde 2 başbakan çıkardıkları bilinmektedir. ${ }^{34}$ Müslüman Mısırlıların eğitime ilgi göstermesiyle birlikte Kıptiler eğitim ve bürokrasideki avantajlı konumlarını yitirdiler. Ancak 1919 sonrasının sekülerleşen Mısır'ında giderek artan biçimde Misırcılık düşüncesi ve Vefd Partisi etrafında birleşmeleri, gerek parlamento temsili gerekse bürokrasi ve eğitim kurumlarındaki görünürlüklerini yeniden arttırd1. ${ }^{35}$ Bununla birlikte Mısırlı Kıptilerin Mısır tarihindeki konumları Mısır kimliği bağlamında tartışılmaya devam etti. Örneğin 20. yüzyılın en önemli Mısırlı tarihçileri arasında kabul edilen ve kendisi de bir Kıpti olan Aziz Suryâl Atiyye, Mısır ulusal tarihi yazılırken dini ve ideolojik sebeplerden dolayı Kıpti tarihinin ihmal edildiğinden yakınıyordu. ${ }^{36}$ Atiyye'nin bu tezi ortaya koyarken dikkat çektiği temel hususlardan biri, Bizans yönetimi altında Mısırlı Kıptilerin milli bir uyanış yaşadığ 1 idi. Atiyye bu durumun edebi eserlere dahi yansıdığını, bu dönemde Kıptilerin Sa'id lehçesiyle yazılı eserler verdiğini söylemektedir. ${ }^{37}$

Kadim Mısırla günümüz Mısırı arasındaki kültürel bağı kurma noktasında Firavuncuların savunduğu en önemli tezlerden biri Said bölgesinde konuşulan dilin antik Mısır'da konuşulan dil ile ortak özellikler gösterdiği idi. Mısır diline ait bazı özelliklerin antik dönemden bu güne taşıyan ise, Araplar Mısır'a geldiğinde Mısır'ın yerlileri konumunda bulunan Kiptiler ve onların konuştuğu dildi. ${ }^{38}$ Bu meyanda Kıptilik ve Kıptice, Mısır'ın öz kimliğinin önemli bir parçası olarak kabul edilmişti ve özellikle Kıpti Fi-

34 1908'de Butros Gali, 1919'da Yusuf Vehbe Paşa.

35 Donald Malcolm Reid, Cairo University, 150.

36 Aziz Suryâl Atiyye, “el-Kenîsetü'l-kıptiyye ve'r-rûhu'l-kavmî fî̀ Misr fi'l-asri'lbîzantî”, el-Mecelletü 't-târîhiyyeti'l-misriyye, III (1950), 1. Atiyye bu dönemde Kıpti kilisesini Mısır milliyetçiliğinin oluşumunda en önemli dönemlerden biri olarak görür. Ona göre Bizans dönemi Mısır'ında Bizans'ın mezhepçi politikalarına karşı gelişen milli şuurun bir merkezi İskenderiye'deki Kıpti Kilisesinde, diğeri yukarı Mısır'ın Suhac şehrinde, Kıptiliğin kurucusu olarak kabul edilen Şennuda'nın yaşadığ 1 yerdeydi. Aziz Suryâl Atiyye, 6.

37 Aziz Suryâl Atiyye, 6.

38 Edebiyatçı İsam es-Settâtî, yukarı Mısır'da bugün konuşulan Arapça'nın Kıpticeden ve Antik Mısır dilinden izler taşıdığını, iki eski dilde olmayan harflerin bugün de pek çok Mısırlı tarafından ya telaffuz edilemediğini, ya da telaffuzunun eski Mısır dillerindeki bazı harflere benzetildiğini kaydeder. Bkz. İsam es-Settâtî, Mukaddime ilâ el-Fulklûr el-Kiptî (Kahire, 2010), 259-265. 
ravuncular tarafindan Arap diline oranla Mısırlılık nosyonuyla daha çok bütünleştiği düşünülmekte idi.

Kıptiliği Arap kimliğine alternatif olarak görenlerin başında Selame Musa gelmektedir. 1887'de Şarkiyye eyaletinde Kıpti bir ailenin oğlu olarak dünyaya gelen Mûsa, Kahire'deki ilk ve orta öğreniminin ardından hukuk tahsili için gittiği Londra'da Batı kültüründen olduğu kadar sosyalizm düşüncesinden de etkilenmişti. 1913'te döndüğü Mısır'da henüz 26 yaşında çıkarmaya başladığı el-Müstakbel adlı dergi sosyalist düşünceleri yaydığı gerekçesiyle yasaklanınca Musa bir köyde öğretmenliğe başladı. Bir yandan kırsaldaki yaşamın onu derinden etkilemesi, diğer yandan halkçılığını besleyen sosyalizm meyli, onun Firavunculuk düşüncesini benimsemesini kolaylaştırmış görünmektedir. ${ }^{39}$ Selâme Mûsa yazılarında genel itibariyle Mısırlıların Arap, Müslüman ya da doğulu olmalarından çok Misırlı oldukları gerçeğine bağlanmaları gerektiği tezini işledi. Bilhassa doğulu olduklarına dair inancın Mısırlılarda bir hastalık haline geldiğini düşündü. Mûsâ'ya göre Misırlıların batılılardan nefret etmesinin ve devamlı surette batının zulmünden bahsetmesinin nedeni de bu "goğululuk hastalığı" idi. Bu hastalıklı doğululuk bilinci aynı zamanda onları Arap kültürüne sadakat duymaya mecbur bırakıyor ve ilerlemelerini engelliyordu. ${ }^{40}$ "Ortaçağ karanlığını temsil eden Arap kültürüne"41 sıkı sıkıya tutunmak anlamsız bir çabayd1. Araplardan zaten daha ileri bir seviyede olan Misırlılar Arap kültürü ve dili üzerine çalışacaklarsa bunu diğer antik medeniyetler üzerine -Arap antikitesi nihai planda başka bir halkın tarihi olarak kabul edilir- çalışır gibi çalışmalı idiler. ${ }^{42}$ Bu düşünceleri Mûsa'nın, yalnızca mu-

39 Arthur Goldschmidt, Biographical Dictionary of Modern Egypt (Cairo: The American University Press, 2000), 139-140. 1916'da Kahire'ye dönen Musa, burada Sosyalist bir parti kurmak istedi ancak muvaffak olamayınca yayıncılık faaliyetlerine ağırlık verdi. 1923'te Corci Zeydan tarafindan kurulan el-Hilâl dergisi editörlüğüne getirildi. 1929 'da buradan ayrılarak el-Mecelletü'l-cedîde adlı bir dergi kurdu. Mûsa'nın en önemli siyasi faaliyeti ise 1935 y1lında Misırc1lık fikrini yayma amaciyla Cem 'iyyetü Misr li'l-Misrî organizasyonunu kurdu. Ami Ayalon, The Press in the Arab Middle East: A Histor (Oxford University Press, 1995), 239.

40 Mûsâ'ya göre bu inanış Mısırlıların Arapların kitaplarını okuyup ezberlemelerine, Arapların tarihine özgü meseleleri inceleyerek zaman kaybetmelerine, İslâmî ilkelere tutunup geri kalmalarına yol açıyordu. Oysa bunların hiçbiri Mısırlıları ilgilendiren şeyler değildi. Bkz. Selâme Musa, el-Yevm ve'l-gad (Medresetu Mûsâ li’n-neşr ve'ltevzî, 1928), 183.

41 Selâme Musa, el-Yevm ve'l-gad, 186.

42 Selâme Musa'ya göre, bölge lehçeleri ana lehçeden çok fazla farklılaştığı için, Arap dili yalnızca kitaplarda olan ölü bir dildir. Bkz. Selâme Musa, el-Yevm ve'l-gad, 183184. 
hafazakar entelektüeller tarafindan değil, Taha Hüseyin ve Mahmûd Abbâs el-Akkâd gibi, Mısırcılık düşüncesine önemli katkılarda bulunmuş seküler çizgideki edebiyatçılar tarafından da eleştirilmesine neden oldu. Taha Hüseyin Musa'yı Şuûbiyye ruhunu diriltmeye çalışmakla itham ederken, Akkâd'a göre Musa'nın Arap kültürüne yönelik eleştirileri onun bir Kıptî olmasindan kaynaklanıyordu. ${ }^{43}$

Musa'nın etnik kökeninin kendisine hatırlatılmasında, Kadim Mısır nosyonunun Kıptî kimliği ile önemli ölçüde özdeşleştirilmesi de önemli bir rol oynamış görünüyor. Kıptîlerin eski Mısır ile daha güçlü bir bağa sahip olduğu şeklindeki düşünceler 1920'li yılların Mısırlıları için hiç duymadıkları türden şeyler değildi. Batılı Mısır-bilim geleneği içerisinde çeşitli vesilelerle dile getirilmiş olan bu tez, ${ }^{44}$ XIX. yüzyılın ikinci yarısından itibaren gelişen Kıptî reformculuğu çerçevesinde de hatırı sayılır bir önem kazanmışt. ${ }^{45}$ Kıptî entelektüeller XIX. yüzyılın sonu ve XX. yüzyılın ilk çeyreğinde kurdukları gazetelere verdikleri; Ramsis, Fir'avn, el-Ahrâm gibi isimlerle bu mirasa olan ilgilerini açığa vurmakta idiler. ${ }^{46}$ Esasında Kıpti cemaati gerek kronolojik açıdan kadim döneme yakınlığı gerekse Müslüman-Arap cemaate nispetle kapalı ve saflığını korumuş bir cemaat olmasına rağmen ${ }^{47}$ özellikle Müslüman kimliği taşıyan aydınlar kadim köken temasını işlerken Kıptî dili ve kültürüne özel bir vurgu yapmaktan kaçınmışlardır. Bu sebeple, kendilerinin gerçek Misırlılar olduğunu savunan Kıpti aydınlar tarafından daha çok benimsendiği görülse de ${ }^{48}$ akımın toptancı bir yaklaşımla Kıptî aydınların hakimiyetine girdiğini iddia etmek doğru olmayacaktır. ${ }^{49}$

43 Musa, Edeb li 'ş-Şa 'b (Selâme Mûsâ li’n-neşr ve'l-tevzî, 1956), 58.

44 Bkz. Stanley Lane-Poole, Cairo: The Sketches of its History, Monuments and Social life (New York, 1973), 205-206; W.M. F. Petrie, Seventy Years in Archeology (London, 1931), 223-224.

45 Ne var ki Malcolm Reid, bu bağı onaylanmakla birlikte Kıptî cemaati açısından fazla önemli bulunmadığını yazar. Bkz. Donald Malcolm Reid, Whose Pharaohs, 280.

46 Donald Malcolm Reid, Whose Pharaohs, 283.

47 Febe Yousry Armanios, aynı dönemde bölgede yaşayan diğer dini azınlıklara nispetle Kıpti cemaatinin Batı ile gerek ekonomik gerekse dini ve ideolojik anlamda daha az temasta bulunduğunu iddia etmektedir. Bkz. Febe Yousry Armanios, Egypt for Which Egyptians? Copts and the Egyptian Nationalist Movement, Basılmamış Yüksek Lisans Tezi (The Ohio-State University, 1998), 15.

48 Febe Yousry Armanios, Egypt for Which Egyptians,? 81.

49 Kahire Üniversitesinde açılan Antik Medeniyet bölümünde tahsil görenler arasında Ezher kökenli öğrenciler ve ulemadan da simalar görülebiliyordu ve oranları hiç de azımsanacak gibi değildi. Donald Malcolm Reid, Cairo University, 50. 
Mısır'da 1922'de Kral I. Fuad ile başlayan krallık dönemi, tıpkı Hidivlik döneminde olduğu gibi, yabancı misyonlarla kraliyet ailesi arasında kurulan müspet ilişkilerin kültür politikalarına da yansıdığı bir dönemdi. Batılı devletlerin kültürel alanda en çok ilgi gösterdikleri Mısır-bilim ve antik dönem kalıntılarına yönelik koruma ve araştırma faaliyetleri de bu müspet ilişkilere paralel olarak kraliyet mensupları tarafından ehemmiyetle takip edilmiştir. Mısır'ın İngiltere tarafından küresel resme biraz daha çekildiği bir dönemde ve 1936 yılında tahta çıkan Faruk dönemi de kültürel politikalarda antik mirasın öne çıkarılması hususunda bazı atılımlara şahit olmuştur. Bununla birlikte 1930'ların ikinci yarısında başlayan ve Avrupa'yı kasıp kavuran savaş atmosferi Mısır'ı da etkilemiş, gerek mali gerekse kültürel açıdan bir durağanlık yaratmıştır. Haziran 1948'de Antik Mısır çalışmalarında gelinen son noktayı el-Mecelletü t-tarihiyye el misriyye adlı ilmi tarih dergisine değerlendiren Abdulmuhsin Bekir, İkinci Dünya Savaşı yıllarındaki mali sıkıntıların bu alandaki çalışmaları etkilediğini not eder. ${ }^{50}$ Savaşın sona ermesinden sonra arkeolojik kazılar yeniden canlılık kazanmak ve pek çok önemli arkeolojik site keşfedilmiş olmakla birlikte, milliyetçi tarih yazıcılığı bağlamında Antik Mısır'a atfedilen önemin 1920'lerdeki kadar yoğun biçimde gözlenmediği görülmektedir. Bununla birlikte kadim köken temasının antik Misır tarihinin Firavun hanedanlar1nın başarısına değil, Mısır halkına mal edilmesi gerektiği şeklindeki algı yaygınlık kazanmaya başlamıştır.

Dönemin Antik Mısır sahasına eğilen önemli tarihçilerinden başında Kahire Üniversitesi Misır-bilim kürsüsünden Selim Hasan (1893-1961) gelmekte idi. Selefi Ahmed Kemal Paşa ve halefi Sami Cebra ile birlikte en büyük 3 Mısır-bilimciden biri olarak kabul edilen ve Mısır Üniversitesinde Ahmed Kemal Paşa'dan Antik Mısır Tarihi ve dili ile ilgili dersler alan Selim Hasan, 1920'li yıllarda Mısır Eğitim Bakanlığı tarafından orta ve yüksek dereceli okullarda okutulmak üzere Mısır tarihine dair bir dizi kitap yazmak üzere görevlendirilmiş, 1921 yılında ise Mısır Müzesi Müdür yardımcılığına atanmıştı. 1922 yılında ilmi bir heyetin başkanlığında gittiği Viyana Üniversitesinde doktorasını tamamladı, aynı dönemde Sorbonne Üniversitesinde de lisansüstü sınıflarına katıldı. 1935 yılına gelindiğinde Mısır-bilim sahasındaki teorik birikimini kazı alanlarında pratiğe dönüş-

50 Abdulmuhsin Bekir, “en-Neşâtu'l-ilmî el-eserî fî mısr min âm 1945 ilâ âm 1947,” elMecelletü't-târîhiyyeti'l-misriyye, I (1948), 179. 
türmesi için Mısır Müzesi ve o zamanki adıyla Kral I Fuad Üniversitesi adına yürütülecek kazıları yönetme göreviyle, 1936'da ise Mısır Tarihi Eserler İdaresi Başkan Vekilliği ile onurlandırıldı. Ne var ki Kral I. Fuad ile olan yakın teması ve ondan aldığı destek, kralın ölümü ve yerine oğlu Faruk'un geçmesiyle sekteye uğradı. Kral Faruk, babasının sağlığında özel bir bölüm kurulması için Mısır Müzesi'ne bağışladığı tarihi eserleri Selim Hasan'dan geri istediğinde, Kahire Sarayı ile arasının açılması pahasına bu teklifi reddetti. ${ }^{51} \mathrm{Bu}$ dönemden sonra idari görevlerinden ayrilıp Antik Mısır'a ilişkin birikimlerini yazıya dökmeye karar verdi ve 1940'lı yıllarda Misır tarihi, dili ve edebiyatına dair bir dizi eser yayınlad $1 .{ }^{52} \mathrm{Bu}$ eserler arasında hem kapsamı hem de meydana getirdiği etki açısından en dikkat çekici olanı Mevsûatu Misr el-kadîme (Antik Mısır Ansiklopedisi) oldu. Selim Hasan'ın kitabının girişinde ortaya koyduğu anlayış, bir bakıma, 1920'lerin Firavunculuğunun iddialarının daha naif ve Mısır'ın o dönemki kültürel vasatı açısından daha makul biçimde dile getirilmesi idi. Zira Selim Hasan, Antik Mısır tarihinin bir Firavunlar Tarihi olarak değil, Mısır halkının tarihi olarak okunması gerektiğinin altını çiziyordu:

"Bu (eserin yazılması); kendine has bir felsefeye, inanca, kültüre, sisteme ve yaşam tarzına sahip kadim ve derin bir halkın tarihini tek bir eserde toplamak istediğim için giriştiğim cüretkar bir çabadır. Fakat bu eseri yazarken ne Firavunlar tarihini Mısır halkının tarihi için model olarak aldım (ki Mısır tarihine ilişkin kitaplarda böyle yapmak adettendir), ne de Firavunların yaşamlarını, gelenek-göreneklerini, nizamlarını, servetlerini ve inançlarını esas alarak Mısır halkının durumu hakkında çıkarımlarda bulundum. Çünkü Firavunlar tarihi ile Mısır halkının tarihi arasındaki fark muhtemelen çok büyüktü, hatta aralarında bir uçurum vardı. Bu sebeple halkın durumunu yazdıklarıma esas aldım. Bu bizi hakikate daha çok yaklaştıracak, hata ve dalalet tuzaklarına düşmekten daha fazla alıkoyacaktır." ${ }^{53}$

Selim Hasan'ın bu satırları, kendisinin Kraliyet ailesi ve tüm devlet makamları ile yollarını ayırdığı dönemin hemen akabinde, Ağustos 1940’ta kaleme almış olması manidardı. Öte yandan bunu sadece kişisel bir hesap-

Selim Hasan, Mevsûatu Mısr el-kadîme (Mektebetü'l-usra, 2001), I, ii-iii.

52 Selim Hasan, en büyük eseri olan Mevsûatu Mısr el-kadîme'nin ithaf bölümünde, kendisini idari görevlerden alanlara, bu tasarruflarıyla dolaylı olarak onu yazmaya teşvik etmiş̧ oldukları gerekçesiyle teşekkür etmişti. Selim Hasan, I, xvi.

53 Selim Hasan, xvi. 
laşma olarak görmek uygun olmayacaktır. Zira hem 1920'lerin Vefd Partisi önderliğindeki liberal siyasetinin sıklıkla eleştirilmeye ve sosyalizm düşüncesinin popülerlik kazanmaya başlaması hem de 1923 'te getirilen anayasal monarşi düzeninin, kralın parlamentoya sık sık ve keyfi yahut İngiliz idaresinin isteği üzerine müdahalede bulunması yüzünden çıkmaza girmesi, 1930'lu yılların sonuna doğru kamuoyunu ve aydınları bezdirmişti. ${ }^{54}$ Selim Hasan da bir taraftan monarşiye ve İngiliz idaresine, bir taraftan da alt ve orta sınıflara mensup Mısırlıların sırtında giderek ağır bir yük oluşturan liberal düzene karşı biriken kollektif öfkenin bir parçası sayılabilir. Hasan'in 1950'li yıllarda Nasır ve ulusalcı rejimle kurduğu iyi ilişkiler ile Nasır'ın kendisini Kahire Müzesi Müsteşarlığına getirmesi de onun fikirlerinin yeni siyasi konjonktürle örtüştügünü göstermektedir.

\section{1952 Devrimi, Nasır ve Milli Tarih Düşüncesinde Yeni-Firavuncu Yönelimler}

Mısır'ın uzun süre yabancı hanedanlar tarafından yönetilmiş olmasının seküler milliyetçi düşünce tarafından ne derece sorunsallaştırıldığ dikkate alınırsa, Cemal Abdunnasır'ın Mısır'da iktidara gelmesinin oluşturduğu hissiyat daha iyi anlaşılacaktır. Nitekim Nasır, Pers saldırılarının son Firavun hanedanını ortadan kaldırdığı 6. yüzyıldan bu yana Mısır'1 yöneten ilk Misırlı olarak, ${ }^{55}$ 19. yüzyıl sonunda filizlenen ve Misır'ın Araplık ve İslam'dan ayrı olarak kendine has bir kültürel mirasa sahip olmasına vurgu yapan Misırcılık düşüncesinin önemli sembollerden biri haline gelmişti. ${ }^{56}$ Nasır'ın, en radikal örneğini Süveyş Kanalı olayında bulan M1sır kurumlarını millileştirme minvalinde yaptığı bir dizi hamlesi arasında, 1858'de Kavalalı Mehmed Ali Paşa tarafindan kurulan ve Nasır darbesine kadar Avrupalı Mısır-bilimciler tarafindan yönetilen Maslahatu'l-âsâri'l-

54 Selma Botman, The Rise of Egyptian Communism 1939-1970 (New York: Sycrause University Press, 1988), xv.

55 Robert Stephens, Nasser: A Political Biography (London: The Penguin Press, 1971), 11.

56 Diasporadaki ünlü Mısır tarihçilerinden Afaf Lütfi es-Seyyid Marsot Nasır yıllarını şöyle tanımlar: "Firavunlar çağından bu yana, iki binyılı aşkın zamandır ilk kez Mısır Misırlılar tarafindan yönetiliyordu. İngiliz silahlarıyla ayakta duran ve desteklenen Türk-Çerkez monarşisi gitmişti. Sonunda yönetilenin kendisini yönetenlere yabancılaşması sona ermiş gibi görünüyordu. Yeni rejim, yerli Mısırlı çoğunluğun din, dil ve etnik yönden kendisiyle özdeşleştirebildiği bir rejimdi." Marsot, Mısır Tarihi: Arapların Fethinden Bugüne, 107. 
mısriyye (Mısır Antik Eserler İdaresi)'nin başına Mısırlı bir Mısır-bilimci atamak ve kurumu doğrudan Kültür Bakanlığı'na bağlamak da vardı. ${ }^{57}$

23 Temmuz İhtilaline ilişkin düşüncelerini kaleme aldığı Felsefetü's-sevra adlı eserinin mukaddimesinde Nâsır, Mısırlıların kendilerini ve kimliklerini keşfetmelerinin, kim olduklarını ve Mısır tarihinde nasıl bir rol oynadıkları sorusunun en önemli soru olduğunu yazmıştır. ${ }^{58}$ Tıpk1 1919 Devrimi'nin entelektüelleri gibi Cemal Abdünnâsır da Türk ve Çerkes asıllı hanedanların hakimiyeti altındaki dönemleri Mısır'ın uğradığı büyük bir felaket olarak tavsif etmiştir. Özellikle Memlüklere ilişkin olarak 20. yüzyıl başı Mısır tarih yazıcılığında gelişen pejoratif tasvir, Nâsır'ın fikirlerinde de en keskin haliyle karşımıza çıkar. ${ }^{59}$ Cemâl Abdunnâsır'a en yakın isimlerden biri olan ve bahsi geçen dönemde el-Ahrâm gazetesi editörlügünü sürdüren Muhammed Hasaneyn Heykel de Nâsır'in Süveyş Kanalının millileştirilmesinin hemen ardından İskenderiye Üniversitesinde yaptığ "Misır'in ruhunun yedi bin yıl sonra nihayet kendilerine geri verildiğinin farkındaydılar" yorumunu yapmıştır. ${ }^{60}$

Nasır'ın Sudan'1 Mısır topraklarına katmak istemesi de Firavuncu düşüncedeki Nil Vadisinin tarihsel ve coğrafi bütünlüğü tezini hatırlatmakta idi. Bu düşünce esasında 1920'lerde Mısırcı aydınlar tarafından sıkça dile getirilmiş bir husustu. ${ }^{61} 1910$ 'lardan beri Sudan'ın Misır ile tarihsel olarak beraberlik içinde olduğunu ve bunun devam etmesi gerektiği fikrini savunan Ahmed Lütfi es-Seyyid'in, Nasır'ın güvendiği siyasi şahsiyetlerden biri olması ve Nasır'ın General Muhammed Necib'ten sonra cumhurbaşkanl1ğını ona teklif etmesi ${ }^{62}$ bu meyanda dikkat çekicidir.

57 Kurum, 2011'de Kültür Bakanlığından ayrılmış ve Vizâratü'l-âsâri'l-mısriyye adıyla ayrı bir tarihi eser bakanlığı oluşturulmuştur. İlk Tarihi Eserler Bakanı ise ünlü Mısırbilimci Zeki Havâs oldu.

58 "(İhtilalle ilgili yazmam) kendimizi keşfetmek, kim olduğumuzu ve birbirine ekli halkalar halindeki Mısır tarihinde nasıl bir role sahip olduğumuzu anlama çabasıdır." Cemal Abdunnâsir, Felsefetü 's-sevra ([y.y.], 1996), 9.

59 Nâsır, "Çerkesler" olarak andığı Memlüklerden, "Mısır'a köle olarak gelip burada efendi olanlar" diye bahsetmektedir. Cemal Abdunnâsır, Felsefetü's-sevra, 65. Nâsır, Mısır'ın sindirilmişliğinin esas itibariyle Memlük hakimiyetinde kademeli olarak gerçekleştiğini savunmaktadır. Cemal Abdunnâsır, Felsefetü's-sevra, 67.

60 M. Hasaneyn Heykel, Kahire Dosyası, çev. Berin Büktaş (Ankara: Bilgi Yayınları, 1974), 84.

${ }^{61}$ Charles Wendell, The Evolution of Egyptian National Image, 261-262.

62 Afaf Lütfi es-Seyyid Marsot, Mısır Tarihi: Arapların Fethinden Bugüne, 108. 
Şüphesiz ki Nasır'ın fikirleri ülkesini yalnızca siyaseten değil, kültürel açıdan da derinden etkilemiştir. Öyle ki yüzyılın başında muhafazakar Hizbu'l-vatanî grubunda siyaset yapmış, muhafazakar milliyetçi hareketin tarihini ve onun liderlerinin biyografilerini yazmış Mısırlı tarihçi Abdurrahmân Râfi‘î (1889-1966), Nasır dönemini takiben daha şiddetli fakat daha az dini referans içeren bir Mısırcılık ideolojisini benimsemiş görünmektedir. ${ }^{63}$ Râfi'î, 23 Temmuz Devriminden 7 y1l sonra 1959 yılında kaleme aldığ 1 Tarîhu hareketi'l-kavmiyye fì misr el-kadîme: Min fecri'ttârîh ilâ fethi'l-arabî (Antik Mısır'da Milli Hareket Tarihi: Tarihin Başlangıcından Arapların Fethine Kadar) adlı eserinde Firavunlar dönemini 1920'lerdeki kadim köken temasını hatırlatacak şekilde, Mısır milli tarihinin altın devirlerinden biri olarak resmetti. Bu eserinde Misır'ın istilalar ve yabancı hükümdarlarla olan meselesini antik döneme dayandıran Râfîi, esere konu ettiği milattan önce 4. binyıldan milattan sonra 7. yüzyıla kadar geçen sürede Mısır halkının çok kez saldırı ve istilalara maruz kaldığını, hiçbir zaman başka millet ve devletlere boyun eğmediğini ve istilacıları eninde sonunda Mısır'dan çıkardıkları tezini işledi. ${ }^{64}$

Râfi'î’nin bu düşünceleri onu Mustafa Kamil ve Hizbu'l-Vatanî çizgisinden koparak daha seküler bir milli hareket geliştiren Ahmed Lütfi es-Seyyid ve es-Siyâse grubuna yaklaştırmıştı. Ancak o yine de Mustafa Kamil'i Mısır'da milli hareketin yakın dönemdeki ilk lideri olarak görmekten vazgeçmemiş̧i. Nitekim Râfî́'í’nin milli harekette muhafazakarlık ve dini referanslara hürmeti esas alan anlayışı 1950'lerin ideolojik açıdan nasyonal sosyalizme yaklaşan Mısır'ında da devam etti. Hatta Râf'’̂̀'nin bu dönemde yazdığı eserlerdeki bazı seçimleri dikkate alınırsa, İslam kimliğini Arap kimliğinin üzerinde tuttuğunu düşünmek yanlış olmayacaktır. Nâsır'ın Arap milletlerinin birliğini yücelten söylemine karşın, Râfi‘î yukarıda bahsi geçen eserinin başlığında, Mısır'ın milli hareket ruhunun son bulduğunu yahut sekteye uğradığını ima eden gelişmeyi "İslam Fethi” yerine "Arap fethi” diye adlandırmayı uygun bulmuş görünmektedir. Onun yaklaşık 80

63 Onun yetiştirdiği ve dönemin önde gelen hukukçularından biri olan Hilmi es-Sibâî Şahin, onun Mısır'ın antik tarihi hakkında yazdığı kitabı takdim ederken, bu girişimin Râfi'î’nin yakın çevresi tarafından şaşkınlıkla karşılandığını yorumunu yapmıştır. Abdurrahmân er-Râfîî, Târîhu hareketi’l-kavmiyye fî mısr el-kadîme: Min fecri 't-târîh ilâ fethi'l-arabî (Kahire: Dâru'l-meârif, 1959), 7.

${ }^{64}$ Abdurrahmân er-Râfi 'î, Târîhu hareketi'l-kavmiyye fî̀ misr el-kadîme: Min fecri'ttârîh ilâ fethi'l-arabî, 68-71. 
y1l süren uzun hayatında gönül verdiği ve gerek bir tarihçi ve gerekse bir hukukçu olarak hizmet ettiği milliyetçi hareketi anlatmak amacıyla yazdığı eserler arasında Arapların fethinden Hidivlik idaresine kadar geçen dönem hakkında hiçbir eser bulunmaması da bu meyanda dikkat çekicidir. ${ }^{65}$

Abdurrahman er-Râfi'î’nin Eski Mısır'daki milli duygular dışında dikkat çektiği bir başka nokta da tek tanı inancının Mısır'a ve Mısırlılara yabanc1 olmadığ 1 düşüncesiydi. Kitabının Akhenaton bahsinde 1907 tarihinde Mısır'ın ilk yerli Mısır-bilimcisi sayılan Ahmed Kemal Paşa'nın kendilerine verdiği bir dersten bahsetmiş, Ahmed Kemal'in kendilerine, Batılı misyonların kadim Mısır medeniyetine ön yargı ile yaklaştığından yakındığını aktarmıştır. Râfi‘î’nin eseriyle aynı dönemde Misr el-fir 'avniyye adlı eseri kaleme alan Kahire Üniversitesinde Antik Mısır Tarihi hocası olarak görev yapan Ahmed Fahri de eserinde Batılı Mısır uzmanlarının bir Doğu halkı olarak Mısır hakkında objektif olmadığını, Mısır halkını yabancı tahakkümü altında parçalanmış bir kavim olarak gördüklerini ve günümüz Mısırlıları ile antik dönemdeki Mısır sakinleri arasında hiçbir bağ kalmadığını iddia ettiklerini, bu sebeple kadim Mısır'ın tarihini Mısırlı tarihçilerin yazmasının daha yerinde olacağını ifade etmiştir. Ahmed Fahri, 1920'lerin kadim köken temalı eserlerinde öne çıkan, Nil Vadisinin bütünlüğü, özellikle Yukarı Mısır'daki Mısırlıların eski Mısırlılarla genetik açıdan kuvvetli bir bağı bulunduğu, kadim Mısır ruhunun kültürel olarak da günümüz Mısır'1-

65 Bununla birlikte bahsi geçen telifinin son bölümünde Arap-İslam fetihleri ile ilgili değerlendirmelerini de okuyucuyla paylaşmış ve Mısır halkının konumu gereği nesep açısından kendisini Araplara daha yakın gördügünü, bu sebeple Müslüman Arapları bir fatih ya da istilacı gibi değil kurtarıcı gibi değerlendirdiklerini yazmıştı. Abdurrahmân er-Râfi'î, Târîhu hareketi'l-kavmiyye fì misr el-kadîme: Min fecri't-târîh ilâ fethi'larabî, Eserinde Müslüman Arapların Mısır'ın fethine de ayrıntılı olarak yer veren Râfi ‘̂̀, Mısır'daki yerli halkın Roma idaresinden duyduğu rahatsızlığın fetihleri kolaylaştırdığı yönündeki kanıyı tekrarlamış, Amr b. El-As'ın İskenderiye kütüphanesini yaktırdığı yönündeki haberlere şiddetle karşı çıkmış ve delillerle çürütmeye çalışmıştır. Bkz. Abdurrahmân er-Râfîi, Târîhu hareketi'l-kavmiyye fì mısr el-kadîme: Min fecri 't-târîh ilâ fethi'l-arabî, 207, 210. Râfi'î'nin Misırlıları ortaçağlardan itibaren Arap olarak gördüğün̈, yukarıda bahsedilen eserinde Hiksos hanedanına karşı Mısırlıların verdiği bağımsızlı mücadelesi hakkında yazdığı satırlarda da görmek mümkündür. Eserde Suriye'den M.Ö. 18. Yüzyılda gelen Hiksoslar'dan ve Misır halkının onlara karşı verdiği mücadeleden de bahseden Râfî̀, Araplar arasından bu kahramanlığı yazılı bir destan haline getirebilecek bir Homeros çıkmasını umduğunu dile getirmişti. Bkz. Abdurrahmân er-Râfi'î, Târîhu hareketi’l-kavmiyye fì misr el-kadîme: Min fecri 't-târîh ilâ fethi'l-arabî, 71 . 
nın kimliğini belirlediği ve yabancı idarelerden kurtuluşun milli hafızada kodlanmış olduğu gibi tezleri de bahsi geçen eserinde tekrarlamıştır. ${ }^{66}$

\section{Mısır Popüler Kültüründe Antik Mısır}

1990'lı yıllarda Mısır'daki yayıncılık faaliyetlerine bakıldığında Mısır Tarihine ilişkin akademik eserlerin ve ders kitaplarının yanı sıra, popüler tarih kitaplarının da yazılmaya başladığı görülür. Bunlar arasında özellikle Firavun mezarlarına ilişkin efsanevi anlatıların yer aldığ 1 ve gerçek ile kurgusal unsurların bir arada bulunduğu kitaplar fazlaca ilgi görmüştür. Nitekim Misırlı yazar Enis Mansur'un Tutankamon'un mezarının lanetli olduğu efsanesi üzerine yazdığı ve ilk baskısını 1978'de yapan Firavunların Laneti ve Akıl-ötesi Bir Şey adlı eseri ilk yıllarda fazla ilgi görmese de, 1992, 1993, 1995 yıllarında arka arkaya yaptığı baskılarla geniş okuyucu kitlelerine ulaşmıştır. Çocuklar için ise Abdulbârî Afâf tarafından hazırlanan ve Muhammed Kutub tarafindan resimlenen bir dizi hikaye kitabi yine 1990'lı yıllarda basılmıştır. ${ }^{67} \mathrm{Bu}$ dönem aynı zamanda semavi dinlere ait metinlerdeki Firavun algısına dair pek çok çalışmanın da yayınlandığ bir dönem olmuştur. ${ }^{68}$ Antik Mısır'a dair eserlerin basıldığ yayın evleri incelendiğinde biri özel kuruluş diğeri kamu kuruluşu olan iki yayınevinin oransal olarak ön plana çıktığı görülecektir: Kahire'de popüler bir özel yayınevi olan Medbûlî ve Misır Devlet Kütüphanesi'ne bağlı bulunan Misır Genel Kitap Organizasyonu (el-Hey'etü'l-mısriyyetü'l-âmme li'l-kutub). (Bkz. Grafik 2) 1971'de hükümet kararıyla kurulan bu organizasyon, bilhassa 1990'lu yıllarda antik Mısır tarihiyle ilgili pek çok telif eser basmıştır. Bu eserlerin müellifleri arasında aslen mimar olmakla beraber Misır tarihi konusundaki popüler çalışmalarıyla da tanınan Seyyid Kerim'i zikretmeliyiz. Zira Kerîm, Firavunlar dönemi Mısır'ında din, toplum, edebiyat ve mimariye kadar pek çok alanda eser vermiştir. ${ }^{69}$ Bütün yayınevleri

${ }^{66}$ Ahmed Fahrî, Misr el-Fir'avniyye (Kahire: el-Hey'eti'l-mısriyyeti'l-âmme li'l-kütüb, 2012), 8-9.

67 Birkaç örnek için bkz. Afâf Abdulbârî, Khufû ve acâibu 's-sihr (Kahire: Dâru'l-fikri'l-arabî, 1997); Mugâmerât Sînûhî (Kahire, 199?) ; Nefertiti (Kahire: Dâru'l-fikri'l-arabî, 199?).

68 Bazıları; el-Baba Şennûda es-sâlis, Mûsâ ve Fir'avn (Kahire: el-Külliyyetü'lklerîkiyye, 1990); Gattâs Abdülmelik el-Haşebe, Rıhletu benî isrâil ilâ mısr elfir 'avniyye ve'l-hurûc (Kahire: Dâru'l-hilâl, 1990); Saîd ebû'l-'Ayneyn, el-Fir'avn ellezî yutâriduhu'l-yehûd beyne 't-tevrâti ve'l-kur'ân (Kahire: Ahbâru'l-yevm, 1997).

69 Seyyid Kerîm, el-Mer'etü'l-misriyye fì ahdi'l-ferâine (Kahire: el-Hey'etü'lmisriyyeti'l-âmme li'l-kütüb, 1994). 
bir arada değerlendirildiğinde ise, 20. yüzyılda Antik Misır temalı eserlerin yaklaşık olarak çeyreğinin devlet inisiyatifi ile, geri kalanının ise özel kuruluşlar tarafından basıldığı anlaşılmaktadır.

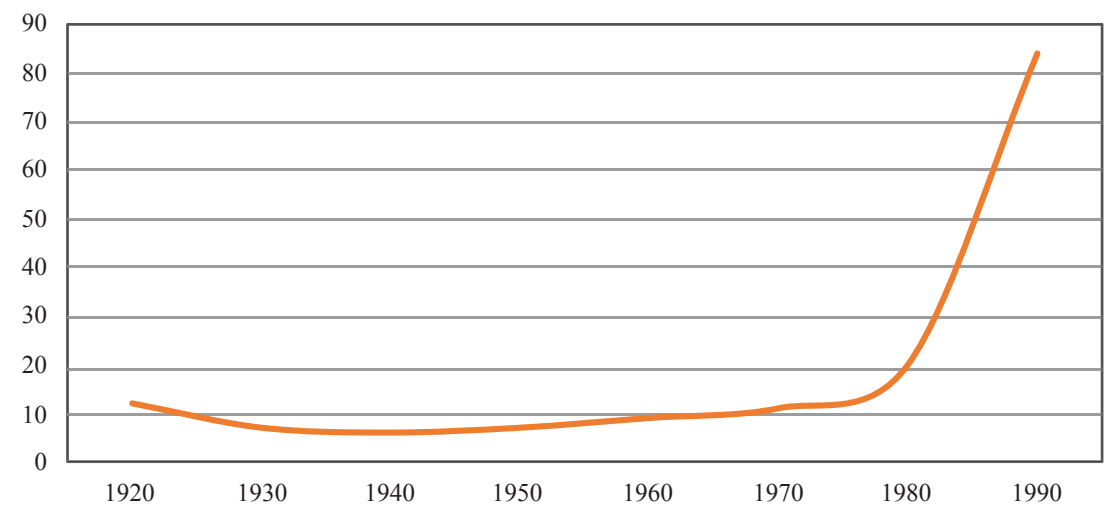

Grafik 1. Mısır'da antik dönemi konu alan ve Arapça olarak basılmış tarih kitaplarının on yıllara göre dağılımı (İskenderiye Kütüphanesi kataloğu esas alınmıştır.)

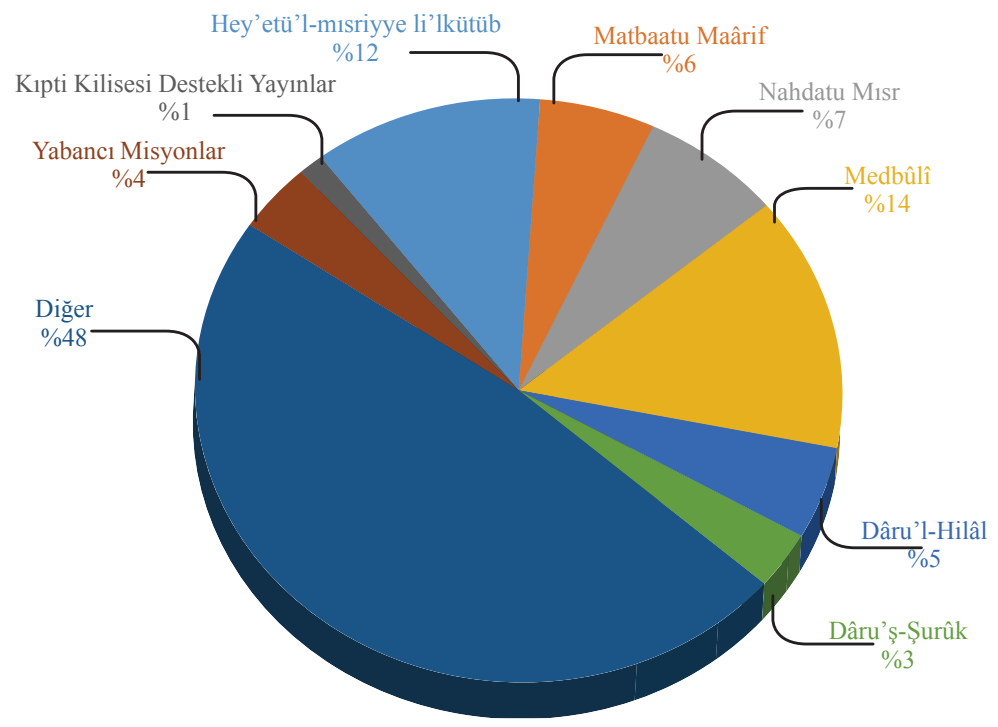

Grafik 2. XX. yüzyılda Mısır'da doğrudan Antik Mısır'ı konu alan ve Arapça olarak basılan tarih kitaplarının yayınevlerine göre dağılımı. 
Antik Mısır tarihine yönelik kitaplarda 1990'larda görülen artış elbette genel olarak kitap basımındaki artışla da ilgilidir. Fakat kadim köken temasının 90'lardaki tek tezahürü bu alandaki yoğun yazın faaliyeti değildi. 1940'l1 ve 50'li y1llarda kurulan pek çok kurum için 1990'lardan itibaren tasarlanan logolarda Antik Mısır'a ait ögeler yoğun olarak kullanıldı. 1950 y1lında Kahire'nin hemen yanı başında bulunan ve antik dönemde Aşağ Mısır'a başkentlik de yapmış olan Heliopolis' ${ }^{70}$ çok yakın bir mevkide kurulan bir üniversiteye, Heliopolis kelimesinin Arapça karş1lı̆ 1 olarak Ayn Şems adı verilmişti. Bu üniversitenin 90'larda hazırlanan logosu, ortada bir obelisk ve her iki yanında bedenleri obeliske, yüzleri dışarıya dönük birer Horus şahini bulunacak biçimde tasarlanmıştır (Bkz. şekil 1). Kahire Üniversitesi için yapılan logo seçimi de bu süreçle benzerlik gösterir. 1946-47 yıllarında yine Kahire Üniversitesi hocalarından Samî Cebr tarafından Yukarı Mısır'da yürütülen Hermopolis kazılarında kendisi adına yapılmış bir mabede rastlanan ve fazlaca popüler merak uyandıran, eski Mısırlıların ilim ve bilgelik tanrısı Tot $^{71}$ yeni yüzyılın başında üniversitenin simgesi haline gelmişti. Nitekim 1990'l1 y1llarda Kahire Üniversitesi için yapılan logo tasarımları arasında Rektör Câbir Nassar'ın özel isteği üzerine öne çıkan tasarım, Tot'un elinde bir tablet ve kalemle resmedilmiş hali oldu. Bu tasarım 2000'li yıllarda Kahire Üniversitesi'nin logosu olarak kabul edildi (Bkz. Şekil 2). Bugün Mısır'da pek çok devlet kuruluşuna ait flamalar ve logolarla birlikte, özellikle 20. yüzyıl boyunca kadim köken temasında sıkça kullanılan Yukarı Mısır'a ait eyaletlerden Minya, Luksor, Kefru'ş-şeyh ve Suhac eyaletlerinin flamalarında da antik Misır ögeleri boy göstermektedir.

70 Heliopolis, Aşağı ve Yukarı Mısır'ın birleştiği dönemde Mısır'ın siyasi ve dini merkeziydi. Encyclopedia of Ancient Egypt, ed. Margaret R. Bunson (New York, 2002), 164.

71 Encyclopedia of Ancient Egypt, ed. Margaret R. Bunson, 405. 


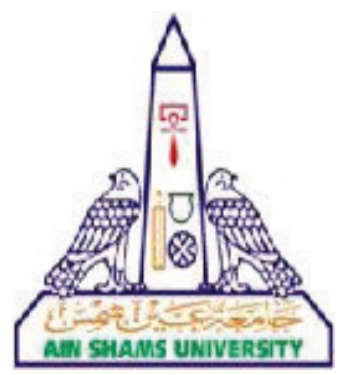

Şekil 1. Ayn Şems Üniversitesi’nin logosu

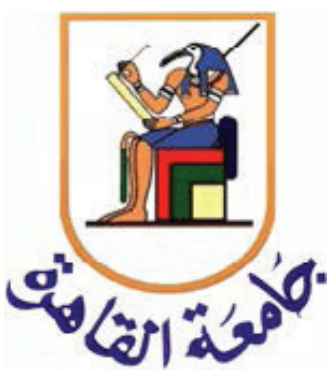

Şekil 2: Kahire Üniversitesi'nin $\operatorname{logosu}$

Kültür kurumlarının logo tasarımlarında da benzer seçimler yapılmıştır. Antik Misır alanında en çok kitap yayınlayan yayınevlerinden olan bugün hala Mısır Ulusal Kütüphanesi'ne ait binada hizmet vermekte olan elHey'eti'l-misriyyeti'l-âmme li'l-kütüb yayınevinin amblemi de antik Misır giysileri içinde bir Mısırlıyı kitap okurken tasvir etmektedir (Bkz. Şekil 3).

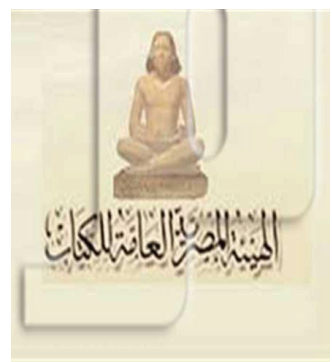

Şekil 3. 1971'de kurulan el-Hey'eti'lmısriyyeti'l-âmme li'l-kütüb logosu

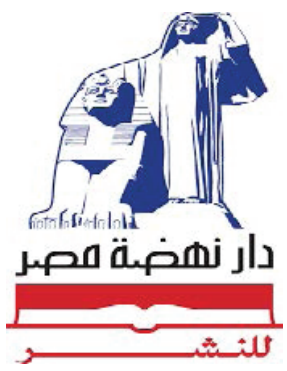

Şekil 4. 1938'de kurulan Nahdatu Mısr Yayınevi logosu

90'l1 y1llarda en önemli gelir kaynaklarından biri turizm olan Misır' da $^{72}$ antik döneme ait kalıntıların devlet eliyle korunması hala sağlıklı bir şekilde gerçekleştirilememektedir. Özellikle Ocak Devrimi sırası ve sonrasında gerek Kahire Müzesindeki gerekse diğer ören yerlerinde görülen yağma girişimleri, devletin kültür politikalarındaki bu açığı gözler gözler önüne

72 Leila Vignal, "The New Territories of Tourism in Egypt: A Local-global Frontier?," Espace, Société, Territoire, Article 509, (Ekim 2010), pr. 50. 
sermiştir. ${ }^{73}$ Devrimi takip eden otorite boşluğunun yol açtı̆̆ bu yağmalarda dikkat çeken noktalardan biri de, hem Kahire'de hem de diğer şehirlerde halkın önemli bir kısmının bu yağmalara karşı antik eser ve kalıntıları korumaya çalışmaları olmuştur. Oysa Mısır hükümetlerinin tavrı uzunca bir dönem özellikle kırsal kesimdeki halkı, tamamen turistik değeri bakımından değerlendirilen müze ve ören yerlerine sokmama yönünde olmuştur. Buna rağmen halkın bir kısmı silah taşıyan ve suç organizasyonu olarak çalışan gruplara karşı antik mirasa sahip çıkması oldukça dikkat çekicidir.

\section{Sonuç}

1881'de İngiltere'nin Mısır'ı işgal etmesi ve I. Dünya Savaşını takip eden Osmanlı Devleti'nin çözülme sürecinin ardından 1924'te Hilafetin kaldırılması, Modern Mısır'ın kaderini belirleyen olayların başında gelmektedir. 20. yüzyıl başlarında Mısır kamuoyunun kolektif bilincindeki en önemli soru/n Misır'ın yazgısının nasıl belirleneceği ve daha da önemlisi, bunu kimin belirleyeceği olmuştur. Bu soru/n Mısır'da tarih yazıcılığı sahasına da hâkim olmuş, milli tarih meselesi tarih yazımının temel meselesi haline gelmiştir. Bu çerçevede 1920'lerde geliştirilen tezlerden biri de, Modern Mısır'ın hem genetik hem de kültürel kodlarının Antik Mısır'dan alınd1ğ1, birbirinden kopuk gibi görünen iki dönem arasında bilhassa yabanc1 kültürlerden en az etkilenen Yukarı Mısır halkının köprü vazifesi gördüğü teziydi.

Ortaya çıktığ1 1920'lerde kadim köken teması Araplık ve Müslümanlığa alternatif üst kimlik iddiasıyla ortaya çıkarken, Nasır döneminde muhafazakar milliyetçi değerlerle bütünleşmiş ve Mısır kimliğinin 3 bileşeninden biri olarak daha makul bir konuma oturmuş görünmektedir. Bu meyanda Nâsır'ın, Arap kamuoyuna karşı Arap halklarını birleştirmenin önemini vurgularken uluslararası arenada ve kültür politikalarında antik mirası ve kadim köken temasını ön plana çıkardığı anlaşılmaktadır. 1920'lerin Firavuncu düşüncesinde Sudan ve Mısır'ın Nil Vadisindeki birlikteliğini ve Mısır'ın istilacılarını eninde sonunda topraklarından çıkardığı temalarını vurgulayan söylemi, Nasır döneminin emperyalizm karşıtı havasında ye-

732011 Mart'inda el-Ahrâm'da çıkan bir haberde, 25 Ocak Devrimi'nin antik dönem kalıntıları konusundaki politikayı kötüden berbata çevirdiği yorumu yapılmıştır. Nevine el-Aref, "Guardians of Guards," el-Ahrâm Weekly, 24 Mart 2011. 
rini bulmuş ve Antik Mısır'a devlet düzeyinde gösterilen ilgi bir kez daha görünür hale gelmeye başlamıştır. Başlangıçta daha çok ideolojik nitelikte olan bu yönelim, 1990'lı yıllarda devletin önemli gelir kaynaklarından biri haline gelmeye başlayan turizme yönelik atılımlarla iyiden iyiye benimsenmiş, arkeolojik sitelere yapılan destekler arttırılmış, Antik Mısır'a ait unsurlar kültürel hayata ilişkin devlet atılımlarında sıkça kullanılarak modern Mısır ile Antik Mısır arasındaki bağ vurgulanmaya çalışııııştır.

1920'lerin Antik Misır algısında hanedan-halk ayrımı yapıldığına rastlamak zordur. Bunun yerine Antik Misır, yöneticileri ve halkıyla bir bütün olarak kabul edilmiştir. Ancak özellikle 1940'lardan sonra gelişen halk hareketlerinde kraliyet ailesine yöneltilen eleştiriler, Antik Mısır Tarihi'ne yönelik algıyı da etkilemiş görünmektedir. 1920'lerde Mısır'ın ilk Mısırlı krallarını da kucaklayan kadim köken anlatısı, Nâsır dönemine gelindiğinde artık "halklarına hoyrat davranan zalim yöneticiler" olarak okunmaya başlanan firavunları dışarıda bırakmaya başlamıştır. Nasır dönemi nasyonal sosyalizmi ile bütünleşerek günümüze kadar gelen bu kanaatin izlerini 2011'de Tahrir Meydanındaki gösterilerde Hüsnü Mübarek'in Firavun olarak tasvir edilişinde bulmak mümkündür.

\section{Kaynakça}

Abdunnâsır, Cemal. Felsefetü's-sevra. y.y., 1996.

el-Akkâd, Abbas Mahmûd. Sa'd Zaglûl Zaîmu's-sevra. Kahire: Hindâvî, 2013.

el-Aref, Nevine. "Guardians of Guards." el-Ahrâm Weekly. 24 Mart 2011.

Armanios, Febe Yousry. Egypt for Which Egyptians? Copts and the Egyptian Nationalist Movement (Basılmamış Yüksek Lisans Tezi). The Ohio-State University, 1998.

Ayalon, Ami. The Press in the Arab Middle East: A History. Oxford University Press, 1995.

Atiyye, Aziz Suryâl. "el-Kenîsetü'l-kiptiyye ve'r-rûhu'l-kavmî fî Misr fi'lasri'l-bîzantî.” el-Mecelletü 't-târîhiyyeti'l-misriyye. 1950.

ebû'l-'Ayneyn, Saîd. el-Fir 'avn ellezî yutâriduhu'l-yehûd beyne't-tevrâti ve'l-kur'ân. Kahire: Ahbâru'l-yevm, 1997. 
Bedevî, Ahmed Ahmed. Rifầ 'a Râfí et-Tahtâvî. Lecnetu'l-Beyâni'l-Arabî, 1959.

Bekir, Abdulmuhsin. "en-Neşâtu'l-ilmî el-eserî fî̀ mısr min âm 1945 ilâ âm 1947." el-Mecelletü 't-târîhiyyeti'l-misriyye, I (1948).

Botman, Selma. The Rise of Egyptian Communism, 1939-1970. New York: Sycrause University Press, 1988.

el-Daly, Okasha. Egyptology: The Missing Millenium Ancient Egypt in Medieval Arabic Writings. Australia: Cavendish Publishing, 2005.

Encyclopedia of Ancient Egypt. ed. Margaret R. Bunson. New York, 2002.

Fahrî, Ahmed. Misr el-Fir'avniyye. Kahire: el-Hey'eti'l-misriyyeti'lâmme li'l-kütüb, 2012.

Gershoni, Israel ve Jankowski, James. Egypt, Islam and the Arabs: the Search for Egyptian Nationhood 1900-1930. New York: Oxford University Press, 1987.

Goldschmidt, Arthur. Biographical Dictionary of Modern Egypt. Cairo: The American University Press, 2000.

Görgün, Hilal. "Muhammed Şefik Gurbâl”. DIA.

Gurbâl, Muhammed Şefik. Kitâbu't-târîhi'l-kadîm. Matbaatu'l-hadîse: Kahire, 1927.

Hamza, Abdülkadir. 'Fi'l-Aksûr'. el-Belâg. 21 Haziran 1927.

Hasan, Selim. Mevsûatu Misr el-kadîme, Mektebetu'l-usra, 2001.

el-Haşebe, Gattâs Abdülmelik. Rıhletu benî isrâil ilâ mısr el-fir 'avniyye ve'l-hurûc. Kahire: Dâru'l-hilâl, 1990.

Heykel, Muhammed Hasaneyn. Kahire Dosyası. (çev.) Berin Büktaş. Ankara: Bilgi Yayınları, 1974.

Heykel, Muhammed Hüseyin. "Misr el-hadîse ve Misr el-kadîme". esSiyasetü'l-Usbûiyye. 27 Kasım 1926.

Heykel, Muhammed Hüseyin. Zeyneb. Beyrut, 2006.

Hüseyin, Ahmed. Îmânî. Kahire, 1936.

Hüseyin, Ahmed. “Misr fir'avniyye (3)”. el-Mukattam. 26 Eylül 1930. 
Hüseyin, Ahmed. Nisfu karnin maa 'l-Urûba ve kadiyyâti Filistîn. Sidon 1971. Hüseyin, Taha. Müstakbelü's-sekâfe fî Misr. Kahire: Dârü'l-meârif, t.y.

Kerîm, Seyyid. el-Mer'etü'l-misriyye fî̀ ahdi'l-ferâine. Kahire: elHey'etü'l-mısriyyeti'l-âmme li'l-kütüb, 1994.

Köse, Mustafa. "Heykel ve Milli Edebiyat Hakkındaki Görüşleri” Şarkiyat Araştırmaları Dergisi, vol. 9. (Bahar 2003).

Lane-Poole, Stanley. Cairo: The Sketches of its History, Monuments and Social life. New York, 1973.

Livaoğlu Mengüç, Hilal. Mısır Basınında Hilafet Tartışmaları 1922-1926. İstanbul: Libra, 2018.

Livaoğlu Mengüç, Hilal. Mısır'da Antik Mirasa Dönüş: Firavunculuk Tezi. İstanbul: Libra Yayınları, 2018.

Marsot, Afaf Lütfi es-Seyyid. Mısır Tarihi: Arapların Fethinden Bugüne. (çev.) Gül Çağalı Güven. Tarih Vakfı Yurt Yayınları, 2010.

Muhammed, M. S. Heykel ve's-siyâseti'l-usbâ 'iyye. Kahire, 1996.

Mûsâ, M. İzzet. “el-Edebü'l-Fir'avnî”. es-Siyâsetü'l-Usbûiyye. 3 Ağustos 1929.

Musa, Selâme. el-Yevm ve'l-gad. Medresetu Mûsâ li'n-neşr ve'l-tevzî, 1928.

Musa, Selâme. Edeb li'ş-Şa 'b. Selâme Mûsâ li'n-neşr ve'l-tevzî. 1956.

Mübarek Paşa, Ali. el-Hitatu 't-tevfikiyye. Kahire, 1990.

Petrie, W.M.F. Seventy Years in Archeology. London, 1931.

er-Râfîi, Abdurrahmân. Târîhu hareketi'l-kavmiyye fì misr el-kadîme: Min fecri't-târîh ilâ fethi'l-arabî. Kahire: Dâru'l-meârif, 1959.

Reid, Donald Malcolm. Cairo University and the Making of Modern Egypt. Cambridge University Press, 1990.

Reid, Donald Malcolm. Whose Pharaohs: Archeology, Museums and Egyptian National Identity from Napoleon to World War I. Cambridge: Cambridge University Press, 1990.

Sâlih, M. Zeki. "İhyâu hulûki'l-kavmî.” es-Siyâsetü’l-Usbûiyye. 15 Ocak 1927. 
es-Settâtî, 'Issâm. Mukaddime ilâ el-Fulklûr el-Klptî. Kahire, 2010.

Seyfîn, Nâşid. "Misr fir'avniyye lahmen ve demmen" el-Mukattam. 10 Eylül 1930.

Seyfüddîn, İbrahim Nemîr ve diğ. Mısr fì usûri-l-kadîme. Kahire: Mektebetu Medbûlî, 1991.

es-Seyyid, Ahmed Lütfî. Kıssatu Hayâtî. Kahire: Dâru'l-hilâl, 1982.

Shaw, Ian ve Nicholson, Paul. British Musem Dictionary of Ancient Egypt. Cairo: American University in Cairo, 1996.

Stephens, Robert. Nasser: A Political Biography. London: The Penguin Press, 1971.

Şennûda es-sâlis, el-Bâbâ. Mûsâ ve Fir'avn. Kahire: el-Külliyyetü'lklerîkiyye, 1990.

et-Tahtâvî, Rifâ'a Râfi'î. Menâhicü'l-elbâb. [y.y]. 2002.

Vignal, Leila. "The New Territories of Tourism in Egypt: A Local-global Frontier?" Espace, Société, Territoire. Article 509. (Ekim 2010). https://journals.openedition.org/cybergeo/23324?lang=en

Wendell, Charles. The Evolution of Egyptian National Image:From its Origins to Ahmad Lütfi al-Sayyid. Los Angeles: University of California Press, 1972. 